\title{
HUBUNGAN AKTIVITAS FISIK TERHADAP KEJADIAN OBESITAS BERDASARKAN INDEKS MASSA TUBUH DI DESA BANJAROYO KULON PROGO DAERAH ISTIMEWA YOGYAKARTA
}

Diterima: 29-01-2018 。Disetujui: 18-10-2018

http://dx.doi.org/10.21460/bikdw.v3i2.97

\begin{abstract}
Deni Aditya Christianto, Angela Marselly Br Barus, Aquina Nino Dewita Ramadhanti, Agatha Ratna Puspitasari, Prasetyo Ardi Pramudito, Fenty Fakultas Farmasi Universitas Sanata Dharma Yogyakarta
\end{abstract}

Korespondensi: deniadit96@gmail.com

\begin{abstract}
ABSTRAK
Pendahuluan: Obesitas merupakan keadaan kelebihan berat badan yang dapat membawa manifestasi negatif bagi kesehatan. Indeks massa tubuh (IMT) merupakan parameter dalam menentukan seseorang mengalami obesitas atau tidak, parameter ini sering digunakan karena mudah diterapkan, cepat dan memiliki hasil yang tepat. Salah satu faktor yang berperan penting dalam kejadian obesitas adalah aktivitas fisik, yakni segala pergerakan tubuh yang mengeluarkan energi serta membakar lemak.

Tujuan: mengidentifikasi hubungan antara aktivitas fisik ringan, sedang dan berat terhadap kejadian obesitas berdasarkan IMT.

Metode: Penelitian ini merupakan penelitian observasional analitik dengan jenis penelitian potong lintang. Pengambilan sampel dilakukan secara non-random sampling dengan teknik accidental sampling dan didapat responden sebanyak 236 orang. Pengambilan data aktivitas fisik dilakukan menggunakan kuisioner IPAQ dan perhitungan IMT dengan mengukur berat badan dan tinggi badan. Analisis data penelitian ini menggunakan SPSS 22 dengan taraf kepercayaan 95\%.

Hasil: Total responden 236 orang, 148 wanita $(60,91 \%)$ dan 88 pria $(36,21 \%)$, didominasi rentang umur $36-60$ tahun $(77,78 \%)$. IMT 123 orang $(40,37 \%)$ memiliki BB berlebih \& obesitas dan 113 orang $(41,95 \%)$ memiliki BB kurang \& normal.

Kesimpulan: Hasil penelitian menunjukkan tidak terdapat hubungan yang berakna $(p=0,18)$ antara aktivitas fisik berat dan sedang terhadap kejadian obesitas berdasarkan IMT pada warga dewasa di Desa Banjaroyo, Kecamatan Kalibawang, Kabupaten Kulonprogo, Yogyakarta.
\end{abstract}

Kata Kunci: aktivitas fisik, obesitas, indeks massa tubuh 


\title{
THE RELATIONSHIP OF PHYSICAL ACTIVITY TO OBESITY STATUS BASED ON BODY MASS INDEX IN BANJAROYO VILLAGE KULON PROGO SPECIAL REGION OF YOGYAKARTA
}

Received: 29-01-2018。Accepted: 18-10-2018 http://dx.doi.org/10.21460/bikdw.v3i2.97

\begin{abstract}
Deni Aditya Christianto, Angela Marselly Br Barus, Aquina Nino Dewita Ramadhanti, Agatha Ratna Puspitasari, Prasetyo Ardi Pramudito, Fenty Faculty of Pharmacy Sanata Dharma University Yogyakarta
\end{abstract}

Corespondence: deniadit96@gmail.com

\begin{abstract}
Introduction: Obesity is an excess of someone's weight which can cause negative effect for health. Body mass index (BMI) is a parameter used in determining whether someone in an obesity condition or not. Body mass index is often used because it is convenient, rapid, and precise. Physical activity is one of the most influence factor in the cause of obesity. Physical activity contains of our body's movement which need a lot of energy that will burn our body fats.

Purpose: to identify the correlation between high physical activity and moderate physical activity on obesity cases based on body mass index.

Method: This research was an observational analytic research using cross sectional research type. The sampling was taken by non-random sampling with accidental sampling technique and with 236 respondents. Physical activities data was collected using IPAQ questionnaire and BMI calculation measured by body weight and height. Analysis of this research data was using SPSS 22 with confidence interval of 95\%. The conclusion of this study was taken using Chi-square test.

Result: Total respondents 236, 148 female (60,91\%) and 88 male (36,21\%), dominated by age range 36-60 years old (77,78\%). BMI 123 respondents (40,37\%) with overweight and obesity, and 113 respondents (41,95\%) with underweight and normal.

Conclusion: This study showed that there was no significant correlation ( $p$ value $=0,18$ ) between high physical activity and moderate physical activity on obesity cases based on body mass index among adults in Banjaroyo's Village, Kalibawang's Subdistrict, Kulon Progo's Regency, Yogyakarta.
\end{abstract}

Keywords: physical activity, obesity, body mass index 


\section{PENDAHULUAN}

Obesitas merupakan kejadian yang harus diwaspadai karena dapat menyebabkan penyakit dengan morbiditas dan mortalitas yang bersifat degeneratif. Parameter yang sering digunakan untuk menentukan seseorang obesitas adalah menggunakan Indeks Massa Tubuh (IMT). Metode antropometri ini merupakan metode yang tidak invasif, mudah digunakan, cost effective, dipakai secara luas, aman dan teknik yang sederhana. 1,4,14,17,44

Obesitas menjadi masalah kesehatan yang serius di berbagai negara seperti negara berkembang maupun negara maju. Obesitas menyebabkan 2,8 juta orang di dunia meninggal setiap tahunnya. Prevalensi obesitas di seluruh dunia meningkat lebih dari dua kali lipat antara tahun 1980 dan 2014. Menurut data National Health and Nutrition Examination Surveys pada tahun 2009-2010, terdapat sekitar $68,8 \%$ orang dewasa di United States mengalami kelebihan berat badan atau obesitas. Peningkatan prevalensi overweight dan obesitas di Jepang mengalami peningkatan 46\% dari tahun 1976-1982 sebesar $16,7 \%$ menjadi $24 \%$ pada tahun 2000, peningkatan juga terjadi di Cina dari $3,7 \%$ pada tahun 1982 menjadi 19\% di tahun 2002. 1,15,45,47

Prevalensi obesitas pada kelompok dewasa di Indonesia sebanyak $14,76 \%$ dengan prevalensi pada laki-laki 19,7\% dan perempuan $32,9 \%$. Data prevalensi kejadian obesitas di Daerah Istimewa Yogyakarta pada tahun 2007 sebesar $8,3 \%$ dan pada tahun 2013 mencapai lebih dari $15,4 \%$ yang menunjukkan peningkatan yang cukup signifikan hampir dua kali lipat hanya dalam waktu 5 tahun. Prevalensi overweight di kabupaten Kulonprogo sebesar $5,8 \%$ dan obesitas sebesar $6,3 \%$. Prevalensi obesitas di Indonesia yang terjadi di wilayah perdesaan sebesar 9,54\% dengan kata lain obesitas tidak hanya terjadi di perkotaan saja namun ternyata juga terjadi di perdesaan. Penelitian yang dilakukan Sunu menunjukkan prevalensi kejadian obesitas pada orang dewasa yang terjadi di daerah pedesaan sekitar $42,2 \% \quad(32,4 \%$ pada wanita dan 9,8\% pada laki-laki).2,3,25,35,37

Obesitas dapat disebabkan oleh beberapa faktor. Kurangnya aktivitas fisik merupakan faktor risiko utama dari kejadian obesitas. Rendahnya prevalensi dari kejadian obesitas berkaitan dengan tingginya aktivitas fisik. Penilaian aktivitas fisik dapat dilakukan dengan menggunakan kuesioner IPAQ short form. Kuesioner IPAQ sudah banyak digunakan di Asia melakukan penelitian hubungan aktivitas fisik dengan risiko kardiovaskular di Sarawak, dengan hasil penelitian dengan adanya hubungan aktivitas fisik dan pola makan dengan obesitas sentral pada tokoh agama di kota manado, penelitian yang menunjukkan adanya hubungan indeks massa tubuh dengan aktivitas fisik. 4,5,12,13,14,16,22,25,26

Tingkat kejadian obesitas yang cukup tinggi pada daerah pedesaan, terlebih kabupaten Kulonprogo yang memiliki kejadian obesitas yang cukup tinggi. Penelitian ini bertujuan untuk mengidentifikasi hubungan antara aktivitas fisik terhadap kejadian obesitas berdasarkan IMT pada warga Dusun Dlingseng, Plengan, dan Tanjung, Desa Banjaroyo, Kecamatan Kalibawang, Kabupaten Kulon Progo, Provinsi D.I. Yogyakarta.

\section{METODE PENELITIAN}

\section{Desain dan Subjek Penelitian}

Penelitian ini merupakan penelitian observasional analitik dengan rancangan penelitian yang digunakan yaitu potong lintang (cross sectional) untuk melihat hubungan 
antara aktivitas fisik terhadap kejadian obesitas. Responden penelitian yaitu penduduk di Dusun Dlingseng, Plengan, dan Tanjung, Desa Banjaroyo, Kecamatan Kalibawang, Kabupaten Kulonprogo, Yogyakarta yang berumur 18-65 tahun, serta telah menyetujui dan menandatangani informed consent. Informed consent yang berisi tentang informasi penelitian yang sedang dilakukan, pernyataan ketersediaan untuk dilakukan pengukuran antropometri dan wawancara, serta jaminan kerahasiaan data oleh peneliti dan hak responden untuk keluar dan tidak berpartisipasi dalam penelitian, diberikan dengan dijelaskan secara individu oleh peneliti. Pengambilan sampel responden pada penelitian ini menggunakan teknik non-probabilty dengan jenis accidental sampling.

Kriteria eksklusi pada penelitian ini adalah orang dewasa dengan kecacatan fisik sehingga tidak bisa melakukan aktivitas fisik, sedang hamil, tidak menggunakan obat-obatan rutin serta memiliki penyakit kronis, dan tidak mengikuti rangkaian penelitian hingga akhir. Responden yang mengikuti penelitian ini berjumlah 330 responden, hanya 236 responden yang masuk ke dalam kriteria inklusi.

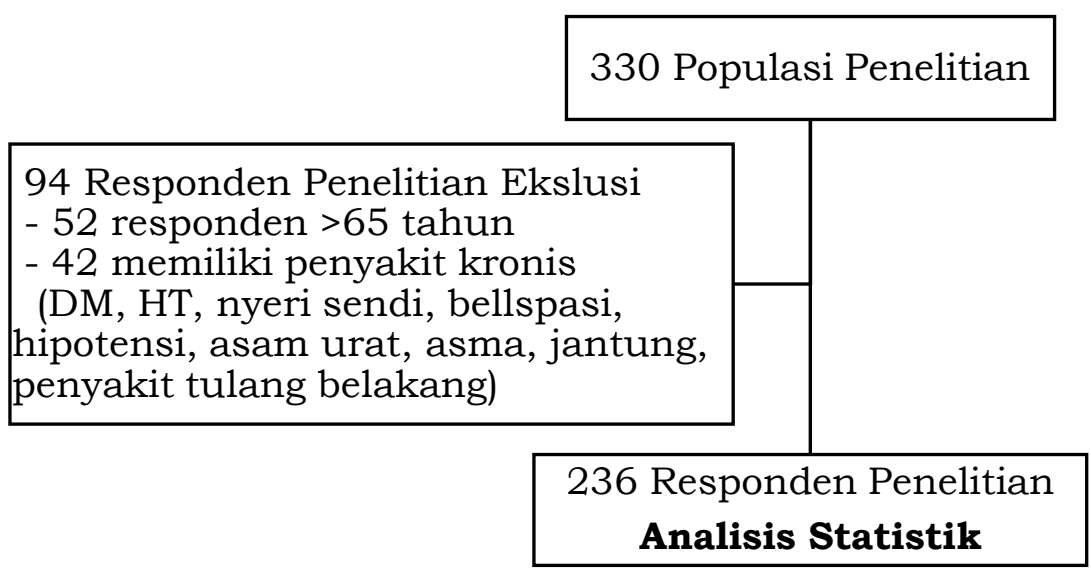

Gambar 1. Proses pengambilan responden

Penelitian yang dilakukan

telah mendapatkan izin dari Pemerintah Kabupaten Kulon Progo Dinas Penanaman Modal Dan Pelayanan Terpadu dengan nomor surat 070.2/00550/V/2017. Prosedur yang digunakan dalam penelitian telah disetujui oleh Komisi Etik Penelitian Kedokteran dan Kesehatan Fakultas Kedokteran Universitas Kristen Duta Wacana Yogyakarta Nomor: 447/C.16/FK /2017. Penelitian melakukan izin di kantor Desa Banjaroyo serta kepala Dusun Dlingseng, Plengan, dan Tanjung.

\section{Pengumpulan Data}

Pengumpulan data yang dilakukan dalam penelitian ini adalah mengukur berat badan, tinggi badan dan aktivitas fisik dengan metode wawancara terstruktur yang mengacu pada pedoman wawancara kuesioner IPAQ versi Short-Form (IPAQ-SF). Alat pengukur berat badan yang digunakan adalah timbangan digital dengan merek GEA Medical dan alat pengukur tinggi badan dengan merek Sature Meter $2 \mathrm{M}$ General Care yang telah divalidasi di Laboratorium Kalibrasi UPT Metrologi 
Legal Yogyakarta. Uji pemahaman bahasa kuisioner dilakukan kepada masyarakat yang memiliki karakteristik yang sama dengan responden penelitian yaitu pada sekelompok orang di Dusun Duren Sawit, Desa Banjaroyo. Analisis data statistik dilakukan di Clinical Epidemiology and Biostatistic Unit (CE\&BU) Fakultas Kedokteran Universitas Gajah Mada Yogyakarta yang dioleh dengan progam IBM SPSS 22 dengan taraf kepercayaan 95\%.

\section{Penilaian aktivitas fisik}

Metabolic Equivalent of Task (MET) merupakan satuan yang digunakan untuk memperkirakan dari energi yang dikeluarkan dari aktivitas fisik. Bedasarkan Automatic report of International Physical Activity Questionnaire (IPAQ) terdapat tiga kategori aktivitas fisik yang dapat dihitung dari Metabolic Equivalent of Task (MET) yaitu kategori berat, sedang dan ringan.

Pengelompokan aktivitas fisik dalam penelitian ini berdasarkan pada kuesioner IPAQ [24] yaitu ringan (MET < $600 \quad M E T$ menit/minggu), sedang (MET $\geq 600$ MET-menit/minggu) dan berat (MET 1500-3000 MET-menit/minggu atau $\geq 3000 \mathrm{MET}$-menit/minggu).

Pada penelitian ini dilakukan pengelompokan kategori aktivitas fisik menjadi 2 kategori yaitu aktivitas fisik sedang dan tinggi. Pada penelitian ini aktivitas fisik ringan hingga sedang dikategorikan menjadi aktivitas fisik sedang dan aktivitas fisik yang berat.

\section{Penilaian Indeks Massa Tubuh (IMT)}

Penilaian IMT pada penelitian ini dilakukan dengan mengukur tinggi badan dan berat badan yang telah di validasi di Laboratorium Kalibrasi UPT Metrologi Legal Yogyakarta. Alat yang digunakan adalah timbangan berat badan dengan merek GEA Medical dengan nomor sertifikat 1079/MET/TC$160 / \mathrm{V} / 2017$ dan alat pengukur tinggi badan dengan merek Sature Meter $2 M$ General Care dengan nomor sertifikat 1079/MET/UP-203/V/ 2017. Pengukuran tinggi badan dilakukan dengan cara badan berdiri tegak lurus dan kepala, bahu, tumit menempel pada papan pengukur tinggi badan. Kepala diselaraskan agar tegak dan pandangan lurus kedepan serta lengan berada disamping badan, tanpa alas kaki. Pengukuran berat badan dilakukan dengan melepas sepatu atau sendal dan menggunakan pakaian yang ringan sehingga tidak mempengaruhi hasil pengukuran berat badan. ${ }^{29}$

Hasil pengukuran berat badan dan tinggi badan responden menurut dimasukkan dalam rumus berikut untuk mendapatkan nilai indeks massa tubuh:

$$
\mathrm{IMT}=\frac{\text { BeratBadan }(\mathrm{kg})}{\text { TinggiBadan }(\mathrm{m}) \times \operatorname{TinggiBadan}(\mathrm{m})}
$$

Pengklasifikasian IMT menurut WHO untuk orang Asia seperti di Indonesia menjadi 3 yaitu, normal 18,5-22,9 kg/m², overweight $\geq 23 \mathrm{~kg} / \mathrm{m}^{2}$, dan obesitas $\geq 25 \mathrm{~kg} / \mathrm{m}^{2}$. Pada penelitian ini IMT sebagai risiko kejadian obesitas dikelompokkan menjadi 2 kategori yaitu kategori berat badan kurang dan normal dengan nilai $\mathrm{IMT} \leq 22,9 \mathrm{~kg} / \mathrm{m}^{2}$ dan kategori berat badan berlebih dan obesitas dengan nilai IMT $\geq 23 \mathrm{~kg} / \mathrm{m}^{2}$. 33,43

\section{Analisis Statistik}

Seluruh analisis data dilakukan di Pusat Kajian CE\&BU dengan menggunakan program IBM SPSS 22 Lisensi UGM Yogyakarta. Profil karakteristik subjek penelitian ditampilkan berdasarkan uji chisquare non-parametrik untuk data kategori dan uji T-Test independent untuk data nominal. Uji untuk 
mengetahui hubungan aktivitas fisik terhadap kejadian obesitas berdasarkan Indeks Massa Tubuh (IMT) dengan menggunakan uji Pearson Chi-square. Dalam analisis uji signifikansi antara data yang diobservasi dengan data yang diharapkan dilakukan dengan taraf kepercayaan 95\%, nilai $\mathrm{p}<0,05$ dipertimbangkan signifikan secara statistik. ${ }^{11}$ Analisis ini telah mendapat kajian etik Komisi Etik Penelitian Kedokteran dan Kesehatan
Fakultas Kedokteran Universitas Kristen Duta Wacana Yogyakarta dengan Nomor: 447/C.16/FK/2017.

\section{HASIL DAN PEMBAHASAN}

Penelitian antara aktivitas fisik dan kejadian obesitas berdasarkan Indeks Massa Tubuh dilakukan pada warga di Dusun Dlingseng, Dusun Plengan, serta Dusun Tanjung dengan total responden yang memenuhi kriteria Inklusi sebanyak 236 orang.

Tabel 1. Profil subjek penelitian Desa Banjaroyo $(n=236)$

\begin{tabular}{|c|c|c|c|c|c|c|}
\hline \multirow{3}{*}{ Variabel } & \multicolumn{4}{|c|}{ Aktivitas Fisik } & \multirow{2}{*}{\multicolumn{2}{|c|}{ Total }} \\
\hline & \multicolumn{2}{|c|}{ Sedang } & \multicolumn{2}{|c|}{ Berat } & & \\
\hline & $\mathbf{n}$ & $\%$ & $\bar{n}$ & $\%$ & $\mathbf{n}$ & $\%$ \\
\hline \multicolumn{7}{|l|}{ Umur } \\
\hline 36-60 tahun & 27 & 11,11 & 162 & 66,67 & 189 & 77,78 \\
\hline $\begin{array}{l}\text { 18-35 tahun } \\
\text { Jenis Kelamin }\end{array}$ & 10 & 4,12 & 37 & 15,23 & 47 & 19,34 \\
\hline Wanita & 23 & 9,47 & 125 & 51,44 & 148 & 60,91 \\
\hline Pria & 14 & 5,76 & 74 & 30,45 & 88 & 36,21 \\
\hline \multicolumn{7}{|l|}{ Pekerjaan } \\
\hline Lain - lain & 23 & 9,47 & 67 & 27,57 & 90 & 37,04 \\
\hline Petani & 14 & 5,76 & 132 & 54,32 & 146 & 60,08 \\
\hline
\end{tabular}

Sebagian besar responden pada Desa Banjaroyo didominasi oleh resonden berjenis kelamin wanita dengan jumlah 148 orang (60,91\%) dari total 236 responden, sedangkan untuk populasi berjenis kelamin pria berkisar 88 orang $(36,21 \%)$ dengan rata-rata berumur sekitar 47 tahun. Hasil analisis profil subjek penelitian di Desa Banjaroyo dengan jumlah subjek 236 orang didominasi memiliki rentang umur 36-60 tahun $(77,78 \%)$ dengan rata-rata berumur sekitar 47 tahun $(47,44 \%)$. Tabel 1 menunjukan bahwa karakteristik responden pada aktivitas fisik sedang dan berat tidak sama dilihat dari jumlah masing-masing variable yang tidak seimbang.
Warga Desa Banjaroyo yang memiliki aktivitas fisik berat didominasi oleh responden berusia 36-60 tahun sebanyak 162 responden $(66,67 \%)$, sedangkan aktivitas fisik berat pada responden dengan usia 18-35 tahun hanya 37 orang $(15,23 \%)$. Hal ini disebabkan karena sebagian besar dari warga dengan rentang umur tersebut memiliki profesi sebagai petani. Tingkat aktivitas fisik pada warga Desa Banjaroto hanya tergolong sedang dan berat tanpa ada yang memiliki aktivitas fisik ringan dan aktivitas fisik berat banyak di masyarakat pedesaan. ${ }^{35}$ 
Tabel 2. Karakteristik subjek penelitian Desa Banjaroyo

\begin{tabular}{lllll}
\hline \multirow{2}{*}{ No } & \multirow{2}{*}{ Variabel } & \multicolumn{3}{c}{ Rerata \pm SD } \\
\cline { 3 - 5 } & & $\begin{array}{c}\text { Aktivitas fisik } \\
\text { sedang }\end{array}$ & $\begin{array}{c}\text { Aktivitas fisik } \\
\text { berat }\end{array}$ & \multicolumn{1}{c}{ Total } \\
\hline 1 & Berat Badan $(\mathrm{Kg})$ & $57,03 \pm 12,22$ & $54,91 \pm 9,78$ & $55,25 \pm 10,20$ \\
2 & Tinggi Badan $(\mathrm{m})$ & $1,54 \pm 0,08$ & $1,54 \pm 0,08$ & $1,54 \pm 0,08$ \\
3 & IMT $\left(\mathrm{Kg} / \mathrm{m}^{2}\right)$ & $24,05 \pm 3,66$ & $23,35 \pm 3,94$ & $23,46 \pm 3,90$ \\
\hline
\end{tabular}

Indeks massa tubuh warga Desa Banjaroyo menunjukkan hanya 123 orang $(40,37 \%)$ yang BB berlebih $\&$ obesitas dan 113 orang (41,95\%) yang memiliki BB kurang \& normal. IMT rata-rata yang didapat masuk dalam rentang risiko obesitas $(\mathrm{BB}$ berlebih) yaitu $23,46 \mathrm{~kg} / \mathrm{m}^{2}$. Tabel 2 menunjukkan bahwa tidak terdapat hubungan bermakna proporsi masing-masing variabel pada aktivitas fisik responden, kecuali pada IMT.

Tabel 3. Hasil analisis aktivitas fisik terhadap IMT

\begin{tabular}{|c|c|c|c|c|c|c|c|c|}
\hline \multirow{2}{*}{ Variabel } & & \multicolumn{2}{|c|}{$\begin{array}{l}\text { BB berlebih } \\
\text { \& Obesitas }\end{array}$} & \multicolumn{2}{|c|}{$\begin{array}{l}\text { BB kurang \& } \\
\text { Normal }\end{array}$} & \multirow{2}{*}{ OR } & \multirow{2}{*}{$\begin{array}{l}\text { IK } \\
\mathbf{9 5} \%\end{array}$} & \multirow{2}{*}{ Nilai $p$} \\
\hline & & $\mathbf{n}$ & $\%$ & $\mathbf{n}$ & $\%$ & & & \\
\hline Aktivitas & Sedang & 23 & 9,75 & 14 & 5,93 & \multirow{3}{*}{0,62} & $0,30-$ & \multirow{3}{*}{$0,18^{a}$} \\
\hline \multirow[t]{2}{*}{ Fisik } & Berat & 100 & 42,37 & 99 & 41,95 & & 1,26 & \\
\hline & Total & 123 & 52,12 & 113 & 4788 & & & \\
\hline
\end{tabular}

aPearson Chi-Square (<0,05 = berhubungan bermakna)

Pada Tabel 3 data menunjukkan tidak terdapat hubungan yang bermakna antara aktivitas fisik dengan kejadian obesitas $(p=0,18)$. Pada ibu-ibu rumah tangga di Ujung Pandang Baru Makassar menunjukkan tidak terdapat hubungan bermakna antara kejadian obesitas dengan variabel aktivitas fisik $(p=0,380)$. Pada wanita usia subur peserta jamkesmas di Puskesmas Wawosana di Manado menunjukkan tidak terdapat hubungan antara aktivitas fisik dengan obesitas. Secara praktis aktivitas fisik yang kurang merupakan faktor utama kegemukan dan obesitas, kurangnya aktivitas fisik akan mempengaruhi keseimbangan pemasukan dan pengeluaran energi seseorang sehingga dapat menyebabkan obesitas. $30,35,38$

Tabel 4. Hasil analisis faktor-faktor lain yang mempengaruhi IMT

\begin{tabular}{|c|c|c|c|c|c|c|c|c|}
\hline \multirow[t]{2}{*}{ Variabel } & & \multicolumn{2}{|c|}{$\begin{array}{l}\text { BB berlebih } \\
\& \text { Obesitas }\end{array}$} & \multicolumn{2}{|c|}{$\begin{array}{c}\text { BB kurang \& } \\
\text { Normal }\end{array}$} & \multirow[t]{2}{*}{ OR } & \multirow[t]{2}{*}{ IK 95\% } & \multirow[t]{2}{*}{ Nilai p } \\
\hline & & $\mathbf{n}$ & $\%$ & $\mathbf{n}$ & $\%$ & & & \\
\hline Jenis & Perempuan & 79 & 33,47 & 69 & 29,24 & & & \\
\hline \multirow[t]{2}{*}{ Kelamin } & Laki-laki & 44 & 18,64 & 44 & 18,64 & 1,15 & $0,68-1,94$ & $0,62^{a}$ \\
\hline & Total & 123 & 52,12 & 113 & 47,88 & & & \\
\hline \multirow{3}{*}{ Umur } & $36-65$ & 103 & 43,64 & 86 & 36,44 & & & \\
\hline & $18-35$ & 20 & 8,47 & 27 & 11,44 & 1,62 & $0,85-3,08$ & $0,14^{a}$ \\
\hline & Total & 123 & 52,12 & 113 & 47,88 & & & \\
\hline \multirow{3}{*}{ Pekerjaan } & Lain-lain & 55 & 23,31 & 35 & 14,83 & & & \\
\hline & Petani & 68 & 28,81 & 78 & 33,05 & 1,80 & $1,06-3,08$ & $0,03^{a}$ \\
\hline & Total & 123 & 52,12 & 113 & 47,88 & & & \\
\hline
\end{tabular}

aPearson Chi-Square (<0,05 = berhubungan bermakna) 
Faktor penyebab obesitas selain aktivitas fisik seperti jenis kelamin, usia, tingkat stress, sosial demografi atau pekerjaan, status merokok, tingkat konsumsi energi dan lemak yang tidak seimbang juga dapat dipertimbangkan mempengaruhi hasil tersebut. Semakin berat stress seseorang semakin tinggi risiko obesitas, dan semakin tua usia semakin tinggi risiko obesitas, namun pada penelitian ini umur tidak menunjukkan hasil yang bermakna (nilai $p=0,14$ ). Penelitian ini memang didominasi oleh perempuan yang memiliki risiko obesitas lebih besar dibandingkan laki-laki, namun hasil yang didapat tidak menunjukkan adanya hubungan yang bermakna (nilai $p=0,62)$. Hubungan faktor sosial demografi dan kegemukan pada penduduk dewasa di Indonesia tahun 2007 dan 2010 menyatakan bahwa kelompok dewasa dengan jenis kelamin wanita, status ekonomi semakin kaya merupakan kelompok yang paling rentan terhadap terjadinya kegemukan. Pada variabel pekerjaan, yang didominasi oleh petani, menunjukan adanya hubungan yang bermakna (nilai $\mathrm{p}=0,03$ ) dengan kejadian obesitas. Petani termasuk jenis pekerjaan dengan aktivitas fisik berat dan responden dengan pekerjaan sebagai petani memiliki tingkat kejadian obesitas lebih kecil dibandingkan dengan pekerjaan lain. 9,32,36,42

Penelitian ini memiliki beberapa keterbatasan seperti penggunaan kuesioner yang membutuhkan data aktivitas fisik 1 minggu sebelumnya, sehingga terdapat kemungkinan bias dalam mengingat aktivitas fisik dengan intensitasnya. Kuesioner IPAQ memang cukup sederhana, kuesioner ini juga tepat digunakan jika ingin menilai semua kegiatan yang mengeluarkan tenaga dalam seminggu tidak hanya kegiatan berat atau olahraga serta semua intensitas kegiatan yang dilakukan selama seminggu, namun responden hanya sering mengingat kegiatan apa yang dilakukan tetapi tidak dapat memperkirakan intensitas waktu yang digunakan secara tepat sehingga dapat menimbulkan bias pada hasil pengukuran aktivitas fisik. Hal ini juga dikonfirmasi pada penelitian lain yang menggunakan IPAQ untuk mengukur aktivitas fisik. Penggunaan IMT untuk mengukur status berat badan di populasi dan menjadi skrining awal untuk mengidentifikasi adanya potensi permasalahan berat badan sudah tepat dipilih, namun tidak dapat dipungkiri pengukuran IMT masih kurang spesifik. IMT tidak dapat membedakan massa otot dengan lemak, sehingga perlu dilakukan pengukuran lebih lanjut yang lebih spesifik. $8,39,38$

\section{KESIMPULAN}

Penelitian tentang hubungan antara aktivitas fisik dan kejadian obesitas telah dilakukan pada warga Desa Banjaroyo, Kalibawang, Kulon Progo, D.I. Yogyakarta dengan total responden sebanyak 236 orang dan didapati kejadian BB berlebih \& obesitas sebesar $52,12 \%$ yang didominasi oleh warga dengan rentang usia 36-65 tahun berjenis kelamin wanita. Hasil analisis uji Chi-Square $\quad(p>0,05 ; \quad p=0,18)$ menunjukkan bahwa tidak terdapat hubungan yang bermakna antara aktivitas fisik terhadap kejadian obesitas berdasarkan indeks massa tubuh.

\section{DAFTAR PUSTAKA}

1. Asia Pacific Cohort Studies Collaboration. The Burden of Overweight and Obesity in The Asia-Pacific Region. Obes.Rev 2007; 8: 191-196.

2. Badan Penelitian dan Pengembangan Kesehatan 
Departemen RI. Laporan Hasil Riset Kesehatan Dasar Provinsi DI Yogyakarta tahun 2007. Jakarta: Departemen Kesehatan RI: 2009;36.

3. Badan Penelitian dan Pengembangan Kesehatan Departemen RI. Laporan Hasil Riset Kesehatan Dasar. Jakarta: Departemen Kesehatan RI: 2013; 1-306.

4. Berrington DGA, Hartge P, Cerhan JR, Flint AJ, Hannan L, Maclnnis RJ, et al. Body-mass index and mortality among 1,46 million white adults. The New England journal of medicine 2010; 363 (23): 211-9.

5. Brock DW, Thomas O, Cowan CD, Allison DB, Gaesser GA, Hunter GR. Association between insufficiently physically active and the prevalence of obesity in the United States. J. Phys. Activ 2009; Health; 6:1-5.

6. Brown DR, Heath GW, Martin SL. Physical Activity Recommendations. In: J. E. Fulton and H. W. Kohl III, eds. Promoting Physical Activity, 2010. Human Kinetics; 27.

7. Cassidy S, Chau JY, Catt M, Bauman A, Trenell MI. Low Physical Activity, High Television Viewing And Poor Sleep Duration Cluster In Overweight And Obese Adults. International Journal of Behavioral Nutrition and Physical Activity 2017; 14;5 : 1-10.

8. Centers for Disease Control and Prevention: Body Mass Index.CDC[Internet].2015[cited 2017 November 26] available from : http://www.cdc.gov/ healthyweight/assessing/bmi/ad ult_bmi/index.html

9. Choi BS, Yang PL, Dobson M, Landsbergis $P$, et al. Sedentary Work, Low Physical Job Demand, and Obesity in US Workers. American Journal of Industrial Medicine. Wiley- Liss; 2010: 1-14.
10. Dahlan MS. Besar Sampel Dalam Penelitian Kedokteran Dan Kesehatan, Epidimiologi Indonesia. Jakarta, 2016; hal. 13-16.

11. Dahlan MS. Statistika Untuk kedokteran dan Kesehatan. Epidemiologi Indonesia. Jakarta: 2016; hal 7,235.

12. Damasanti R. Hubungan Indeks Massa Tubuh Dengan Aktivitas Fisik Wanita Di Perumahan Gedongan Colomadu Karanganyar. Universitas Muhammadiyah Surakarta; 2012.

13. Dewi UP. Hubungan Antara Densitas Energi Dan Kualitas Diet Dengan Indeks Massa Tubuh (Imt) Pada Remaja. Universitas Diponegoro Semarang; 2013.

14. Flagel KM, Kit BK, Orpana $H$, Graubard BI. Association of AllCause Mortality With Overweight and Obesity Using Standard Body Mass Index Categories. American Medical Association. 2013; 309 (1), 71-82.

15. Flegal KS, Margaret DC, Brian KK, Cynthia LO., 2012. Prevalence of Obesity and Trends in the Distribution of Body Mass Index Among US Adults 19992010. JAMA [internet]. 2012 [cited 2017 November 15]; 307 (5), 493.

16. Fogelholm M. Physical Activity, fitness and fatness: Relations to mortality, morbidty and disease risk factors. A systematic review. Obesity Reviews [internet]. 2012 [cited 2017 November 17]; 11(3), 202-221.

17. Gibbons H. Overweight and Obesity. NIHLBI [online]. 2012 [cited 2017 November 18]; available: https://www.nhlbi. nih.gov/ health/healthtopics/topics/obe accessed 9 Desember 2017.

18. Gonzalez AB, Hartge $P$, Cerhan JR, Flint AJ, Hannan L, Maclnnis 
RJ, et al. Body Mass Index and Mortality Among 1.46 Million White Adults. The New England Journal Of Medicine [online].2010 [cited 2017 November 19]; 363 (23), 22112219.

19. Goyton \& Hall. Textbook Of Medical Physiology. 12th Ed. USA: Saunders Elsevier; 2011.

20. Harikedua VT dan Tando. Aktivitas Fisik Dan Pola Makan Dengan Obesitas Sentral Pada Tokoh Agama di Kota Manado. GIZIDO [online].2012; 4 (1): 289298.

21. Hatma RD. Sosial Determinan dan Faktor Risiko Kerdiovaskular. Buletin Jendela Data \& Informasi Kesehatan. 2012; 2(2): 17-18.

22. Hills AP, Andersen LB, and Byrne NM. Physical activity and obesity in children. British journal of sports medicine [online].2011; 45 (11): 866-870.

23. Inoue $\mathrm{S}$ and Zimmet $\mathrm{P}$. The AsiaPacific Perspective: Redefining Obesity and Its Treatment. Australia: Health Communications Australia. 2000.

24. International Physical Activity Questionnaire. Guidelines for Data Processing and Analysis of the International Physical Activity Questionnaire (IPAQ) Short and Long Forms. 2005. 3-6.

25. Kementrian Kesehatan. Profil Kesehatan Indonesia Tahun 2013. Jakarta: Kementerian Kesehatan RI; 2014: 122.

26. Lian CW, Hazmi H, Thon CC, Muda WM. Physical Activity and Cardiovascular Risk Factors Among Malays In Selected Rural and Urban Communities In Sarawak. Malaysian Journal of Public Health Medicine [online].2015; 15 (3): 104-111.

27. Mihardja L and Soetrisno U. Prevalence and Determinant
Factors for Overweight and Obesity and Degenerative Diseases Among Young Adults in Indonesia. Journal of the ASEAN Federation of Endocrine Societies [online]. 2012. [cited 2017 November 21]; 27(1): 77-81. doi: 10.15605/jafes.027.01.12.

28. Asupan energi dan aktivitas fisik dengan kejadian obesitas sentral pada ibu rumah tangga di kelurahan ujung pandang baru kecamatan tallo kota makassar. Mustamin. Media Gizi Pangan [online].2010. [cited 2017 November 23]; 10 (2): hal 60-65.

29. National Health and Nutrition Examination Survey (NHANES). Anthropomerty Procedures Manual In: Examination Protocol. CDC. 2007: 3-3.

30. Novitasary MD, Mayulu N, Kawnginan S, Hubungan antara Aktivitas Fisik dengan Obesitas pada Wanita Usia Subur Peserta Jamkesmas di Puskesmas Wawonasa Kecamatan Singkil Manado, J e-Biomedik (eBM) [internet].2013 [cited 2017 November 23]; 1(2): 1040-1046.

31. Ramadhaniah, Julia M, Huriyati E. Durasi Tidur, Asupan Energi, Dan Aktivitas Fisik Dengan Kejadian Obesitas Pada Tenaga Kesehatan Puskesmas. J Gizi Klinik Indonesia [internet]. 2014 [cited 2017 November 2017 23]; 11 (2): 85-96.

32. Sari K, dan Amaliah N. Hubungan Faktor Sosial Demografi Dan Kegemukan Pada Penduduk Dewasa di Indonesia Tahun 2007 Dan 2010 (Analisis Data Riskesdas 2007 Dan 2010). $\mathrm{J}$ Ekologi Kesehatan [internet]. 2014 [cited 2017 November 23]; 13 (4): 328-339.

33. Segal LM, Rayburn J, Martin A. The State of Obesity. Robert Wood Johnson Foundation. 2016; 20. 
34. Stern JS and Kazaks, A Obesity A Reference Handbook. England: ABC-CLIO. 2009.

35. Sudikno, Milla $H$, and Besral. Hubungan Aktivitas Fisik Dengan Kejadian Obesitas Pada Orang Dewasa Di Indonesia (Analisis Data Riskesdas 2007). J of The Indonesian Nutrition Association [internet].2010 [cited 2017 November 24]; 33(1): 37-49.

36. Sundari E, Masdar H, Rosdiana D. Angka Kejadian Obesitas Sentral Pada Masyarakat Kota Pekanbaru. Jom FK. 2(2):1-16.

37. Sunu UFS. Hubungan Aktivitas Fisik Terhadap Rasio Kolesterol Total/HDL Pada Masyarakat Di Desa Kepuhharjo Kecamatan Cangkringan Sleman Yogyakarta. Fakultas Farmasi Universitas Sanata Dharma. 2016:5.

38. Tomioka K, Iwamoto J, Saeki K, Okamoto N. Reliability and Validity of the International Physical Activity Questionnaire (IPAQ) in Elderly Adults: The Fujiwara-kyo Study. Japan Epidemiological Association. 2011;21(6):459-465.

39. Utami TW, Bebasari E, Ernalia Y. Relationship Of Physical Activity Levels With Genesis Obesity In Faculty Of Medicine University Of Riau Generation $2012 \quad \&$ 2013.JOM FK. 2015; 2(2).

40. Wanner M, Gotschi T, Diener EM, Kahlmeier S, Martin BW. Active Transport, Physical Activity, and Body Weight in Adults a Systematic Review. American Journal of Preventive Medicine. 2012; 42(5): 493-502.
41. Wanner M, Martin BW, Autenrieth CS, Schaffner E, Meier $\mathrm{F}$, et al. Associations between domains of physical activity, sitting time, and different measures of overweight and obesity. Preventive Medicine Reports. 2016;3: 177-184.

42. Widiantini W, Tafal Z. Aktifitas Fisik, Stres, dan Obesitas pada Pegawai Negeri Sipil Jurnal Kesehatan Masyarakat. 2014; 8(7): 335.

43. Widjaja FF, Santoso LA, Barus NRV, Pradana GA, Estetika C. Prehypertension and hypertension among young indonesian adults at a primary health care in a rural area. Med J Indian. 2013; 22:3945.

44. Woodrow G. Body Composition Analysis Techniques In The Aged Adult: Indications And Limitations. Current Opinion in Clinical Nutrition and Metabolic Care. 2009 (12): 8-14.

45. World Health Organization (WHO) World Health Statistics. WHO[Online\}. 2012.Available from

http://www.who.int/gho/public ations/world_health_statistics/2 012/en/

46. World Health Organization Global Health Observatory (GHO) Data. 2016. Available from http://www.who.int/gho/ncd/ri sk_factors/overweight_text/en/

47. World Health Organization, Obesity, WHO [Online]. 2017. http://www.who.int/dietphysical activity/childhood_what/en/ 